\title{
Horizontal Alveolar Ridge Augmentation with Allogeneic Bone Block Graft Compared with Autogenous Bone Block Graft: a Systematic Review
}

\author{
Thomas Starch-Jensen ${ }^{1}$, Daniel Deluiz ${ }^{2}$, Eduardo Muniz Barretto Tinoco² \\ ${ }^{1}$ Department of Oral and Maxillofacial Surgery, Aalborg University Hospital, Aalborg, Denmark. \\ ${ }^{2}$ Department of Periodontology, Rio de Janeiro State University, Rio de Janeiro, Brazil.
}

\author{
Corresponding Author: \\ Thomas Starch-Jensen \\ Department of Oral and Maxillofacial Surgery \\ Aalborg University Hospital \\ 18-22 Hobrovej, DK-9000 Aalborg \\ Denmark \\ Phone: +45 97662798 \\ Fax: +45 97662825 \\ E-mail: thomas.jensen@rn.dk
}

\begin{abstract}
Objectives: The objective of the present systematic review was to test the hypothesis of no difference in implant treatment outcome after horizontal ridge augmentation with allogeneic bone block compared with autogenous bone block.

Material and Methods: A MEDLINE (PubMed), Embase and Cochrane Library search in combination with a hand-search of relevant journals was conducted including human studies published in English through March 13, 2019. Comparative and non-comparative studies evaluating horizontal ridge augmentation with allogeneic bone block were included. Cochrane risk of bias tool and Newcastle-Ottawa Scale were used to evaluate risk of bias.

Results: One comparative study with high quality and 12 non-comparative studies fulfilled the inclusion criteria. Considerable heterogeneity prevented meta-analysis from being performed. The comparative retrospective short-term study demonstrated no significant difference in implant treatment outcome between the two treatment modalities. Non-comparative long-term studies revealed high implant survival, gain in alveolar ridge width and bone regeneration with allogeneic bone block. However, noncomparative studies disclosed high incidence of complications including dehiscence, exposure of allogeneic bone block and partial or total loss of the grafts.

Conclusions: There seemed to be no difference in implant treatment outcome after horizontal ridge augmentation with allogeneic bone block compared with autogenous bone block. However, increased risk of complications was frequently reported with allogeneic bone block.
\end{abstract}

Keywords: alveolar bone loss; alveolar ridge augmentation; dental implants; oral surgical procedures; review.

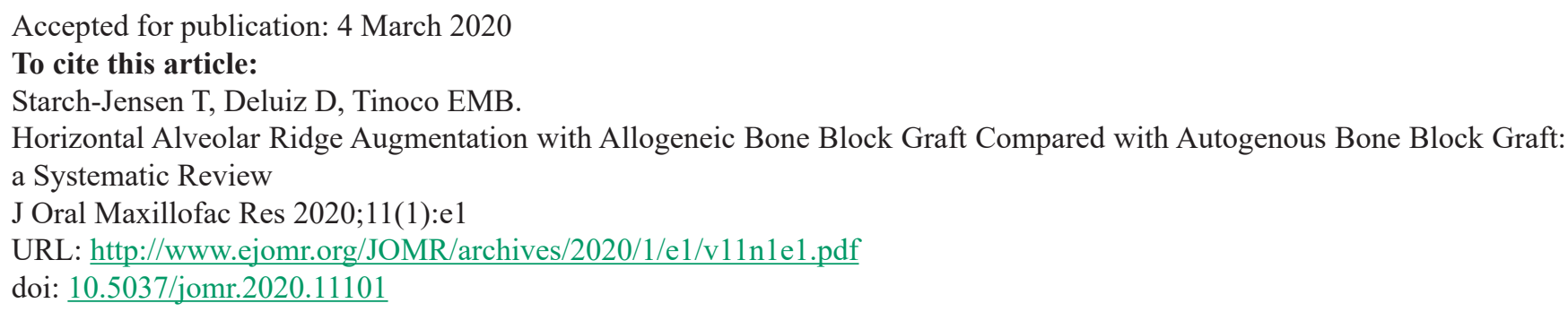




\section{INTRODUCTION}

Alveolar ridge deficiency following tooth loss compromises oral rehabilitation with implants [1]. Horizontal alveolar ridge augmentation (HARA) prior to implant placement is frequently necessary when dimensions of the alveolar process are inadequate [2-4].

Autogenous bone block is considered the preferred treatment modality for HARA with high survival rates of suprastructures and implants [5-10]. However, use of autogenous bone block is associated with risk of donor site morbidity, unpredictable graft resorption and possibility of injury to vital structures [1113]. Allogeneic bone block has been proposed as an alternative in HARA to diminish morbidity and simplify the surgical procedure.

Allogeneic bone graft material derived from genetically non-identical donor of the same species is available as blocks (cortical, cancellous) or as chips or granules (cortical, cancellous). The most commonly used allogeneic bone graft materials are freeze-dried bone allograft (FDA), demineralized freeze-dried bone allograft (DFDA), and fresh-frozen bone allograft (FFA). Systematic reviews and metaanalyses have concluded that allogeneic bone graft is a suitable grafting material $[\underline{14,15]}$. However, allogeneic bone graft is rarely used for HARA compared with autogenous bone graft or other bone substitutes due to risk of immunologic reactions and disease transmission.

HARA with allogeneic bone block has previously been assessed in systematic reviews and metaanalyses reporting high implant survival rates and gain in alveolar ridge width $[\underline{16}, \underline{17}]$. A recent systematic review concluded insufficient evidence is available to establish treatment efficacy relative to graft incorporation, alveolar ridge augmentation, and long-term implant survival after HARA with allogeneic bone block [18]. Moreover, a radiographic and histomorphometric study assessing HARA with allogeneic bone block disclosed statistically significant less vital bone and more graft resorption compared with autogenous bone block graft after 6 - 8 months [19], in accordance with other publications revealing significant more resorption of the augmented area, low rate of graft remodelling and clear signs of inflammation with allogeneic bone block [20-23]. Furthermore, HARA with allogeneic bone block revealed significantly less vital mineralized bone compared with allogeneic bone block impregnated with autologous bone marrow [24]. Therefore, implant treatment outcome after HARA with allogeneic bone block compared with autogenous bone block graft involving clinical, radiographic and histomorphometric outcome measures is presently unknown. The objective of the present systematic review was to test the hypothesis of no difference in implant treatment outcome after horizontal alveolar ridge augmentation with allogeneic bone block compared with autogenous bone block.

\section{MATERIAL AND METHODS Protocol and registration}

Review was conducted in accordance with the Preferred Reporting Items for Systematic reviews and Meta-Analyses (PRISMA) statement for reporting systematic reviews [25]. Methods of the analysis and inclusion criteria were specified in advance and documented in a protocol and registered in PROSPERO, an international prospective register of systematic reviews.

Registration number: CRD42019129754.

The protocol can be accessed at:

https://www.crd.york.ac.uk/prospero/display record. php?ID=CRD42019129754.

\section{Focus question}

Focus question was developed according to the Patient, Intervention, Comparison and Outcome (PICO) framework as described in Table 1.

\section{Eligibility criteria}

Randomized controlled trials, controlled clinical trials, case-series and retrospective human studies assessing implant treatment outcome after HARA with allogeneic bone block compared with autogenous bone block were included in this study. Human studies solely evaluating HARA with allogeneic bone block were included as non-comparative studies.

\section{Types of outcome measures}

- Survival of suprastructures. Estimated by subtracting of failed suprastructures, which is defined as a complete loss of the suprastructure due to technical and/or biological complications.

- Survival of implants. Estimated by subtracting of failed implants, which is defined as mobility of previously clinically osseointegrated implants or removal of non-mobile implants due to progressive peri-implant marginal bone loss and infection. 
Table 1. PICOS guidelines

\begin{tabular}{l|l}
\hline $\begin{array}{l}\text { Patient and } \\
\text { population (P) }\end{array}$ & Healthy patients with a horizontal alveolar deficiency following tooth loss or congenitally missing tooth/teeth. \\
\hline $\begin{array}{l}\text { Intervention (I) } \\
\text { Comparator or } \\
\text { control group (C) }\end{array}$ & Horizontal alveolar ridge augmentation with an allogeneic bone block graft. \\
\hline Outcomes (O) & $\begin{array}{l}\text { Survival of suprastructure, implant survival rate, implant stability, bone-to-implant contact, peri-implant marginal } \\
\text { bone loss, histomorphometric assessment of new bone formation, residual allogeneic bone graft and connective tissue, } \\
\text { gain in alveolar ridge width and volumetric reduction of the augmented area, patient-reported outcome measures, } \\
\text { biologic and technical complications. }\end{array}$ \\
\hline Study design (S) & $\begin{array}{l}\text { Randomized controlled trials, controlled clinical trials, case-series and retrospective studies assessing horizontal } \\
\text { alveolar ridge augmentation with an allogeneic bone block graft compared with autogenous bone block graft. } \\
\text { Moreover, human studies solely assessing horizontal alveolar ridge augmentation with allogeneic bone block graft } \\
\text { was included as non-comparative studies. }\end{array}$ \\
\hline Focused question & $\begin{array}{l}\text { Are there any differences in implant treatment outcome after horizontal alveolar ridge augmentation with an allogeneic } \\
\text { bone block graft compared to autogenous bone block graft? }\end{array}$ \\
\hline
\end{tabular}

- Implant stability. Estimated by magnetic resonance frequency analysis, percussion test or reverse torque test.

- Bone-to-implant contact. Estimated by histomorphometric measurements.

- Peri-implant marginal bone loss. Evaluated by radiographic measurements.

- Histomorphometric assessment of new bone formation, residual allogeneic bone graft and connective tissue.

- Gain in alveolar ridge width and volumetric reduction of the augmented area. Estimated by clinical or radiographic measurements.

- Patient-reported outcome measures.

- Biologic and technical complications.

\section{Information sources}

The search strategy incorporated examinations of electronic databases, supplemented by a thorough hand-search page by page of relevant journals including "British Journal of Oral and Maxillofacial Surgery", "Clinical Implant Dentistry and Related Research", "Clinical Oral Implants Research", "European Journal of Oral Implantology", "Implant Dentistry", "International Journal of Oral and Maxillofacial Implants", "International Journal of Oral and Maxillofacial Surgery", "International Journal of Periodontics and Restorative Dentistry", "International Journal of Prosthodontics", "Journal of Clinical Periodontology", "Journal of Dental Research", "Journal of Oral Implantology", "Journal of Oral \& Maxillofacial Research", "Journal of Periodontology", "Journal of Prosthetic Dentistry", "Journal of Craniofacial Surgery", "Journal of Cranio-Maxillo-Facial Surgery", "Journal of Oral and Maxillofacial Surgery", "Periodontology 2000",
"Oral and Maxillofacial Surgery" and "Oral Surgery Oral Medicine Oral Pathology Oral Radiology". The manual search also included the bibliographies of all articles selected for full-text screening as well as previously published reviews relevant for the present systematic review. One reviewer (T.S-J.) performed the search.

\section{Search strategy}

A MEDLINE (PubMed), Embase, and Cochrane Library search was conducted. Human studies published in English through March 13, 2019 were included. Grey literature, unpublished literature as well as other databases like Scopus, Google Scholar, or Research Gate were not included in the search strategy of the present systematic review. Search strategy was performed in collaboration with a librarian and utilized a combination of Medical subject heading (MeSH) and free text terms. A detailed description of the search strategy is presented in Appendices 1, 2 and 3.

\section{Selection of studies}

PRISMA flow diagram presents an overview of the selection process (Figure 1). Titles of identified reports were initially screened with duplicates removed. Abstracts were assessed when titles indicated that the study was relevant. Full-text analysis was obtained for those with apparent relevance or when the abstract was unavailable. References of papers identified and previously published systematic reviews assessing HARA with allogeneic bone block were cross-checked for unidentified articles. Study selection was performed by one reviewer (T.S-J.). 


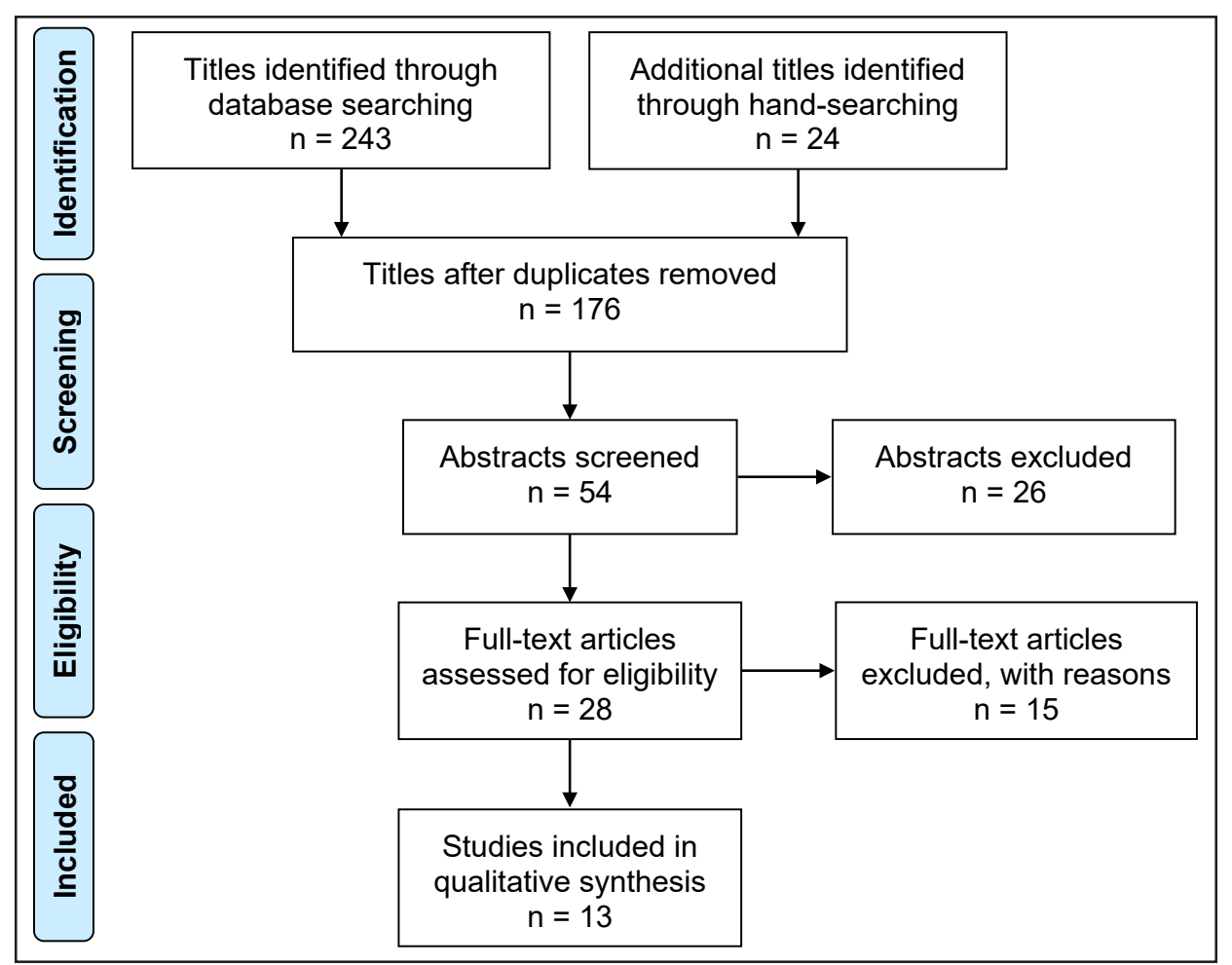

Figure 1. PRISMA flow diagram demonstrating the results of systematic literature search. Electronic search resulted in 243 entries. Twentyfour additional articles were identified through hand-searching. Of these 267 articles, 91 were excluded because they had been retrieved in more than one search. A total of 54 abstracts were reviewed and full-text analysis included 28 articles. Thirteen studies were finally included comprising one comparative study and 12 non-comparative studies.

\section{Inclusion criteria}

Studies assessing implant treatment outcome after HARA with allogeneic bone block compared with autogenous bone block were included by addressing the previously described outcome measures. Review exclusively focused on studies using HARA with block graft and lag-screw fixation prior to implant placement with an observation period after implant loading of at least six months. In addition, at least ten patients should be included and number of implants inserted and surgical procedures had to be clearly specified.

\section{Exclusion criteria}

Following exclusion criteria were applied: unspecified length of observation period, insufficient description of surgical procedures or inserted implants as well as studies involving medically compromised patients. Likewise, HARA with allogeneic bone graft material in combination with a thermoplastic carrier, simultaneous implant placement, use of tunnel or tent pole techniques or titanium-reinforced membranes as well as studies adding growth factors, bone morphogenetic proteins, fibrin glue or plateletrich plasma to the grafting material were also excluded. Moreover, letters, editorials, $\mathrm{PhD}$ theses, letters to the editor, case reports, abstracts, technical reports, conference proceedings, cadaveric studies, animal or in vitro studies and literature review papers were excluded.

\section{Data extraction}

Data were extracted by one reviewer (T.S-J.) according to a data-collection form ensuring systematic recording of the outcome measures. In addition, relevant characteristics of the study were recorded. Corresponding authors were contacted by e-mail in the absence of important information or ambiguities.

\section{Data items}

Following items were collected and arranged in following fields: author, patients, pre-operative alveolar ridge width, study design, surgical site, type of grafting material, graft healing period, number of implants inserted, implant healing period, prosthetics, observation period after functional loading, suprastructure and implant survival, implant stability, bone-implant-contact, peri-implant marginal bone loss (PIMBL), histomorphometric measurements, gain in alveolar ridge width, patient-reported outcome measures (PROM), biologic and technical complications. 


\section{Quality and risk of bias assessment}

Quality assessment was undertaken by one review author (T.S-J.) as part of the data extraction process. Cochrane Collaboration's tool for assessing the risk of bias suggested in the Cochrane Handbook for Systematic Reviews of Interventions was used for included randomized controlled trials (version 5.1.0) [26].

Following items were evaluated:

- Random sequence generation;

- Allocation concealment;

- Patient blinding;

- Outcome blinding;

- Incomplete outcome data addressed;

- Selective reporting.

Publications were grouped into the following categories [27]:

- Low risk of bias (possible bias not seriously affecting results) if all criteria were met;

- High risk of bias (possible bias seriously weakening reliability of results) if one or more criteria were not met;

- Unclear risk of bias when too few details were available for classification as high or low risk.

Newcastle-Ottawa scale was applied for nonrandomized studies to judge each included study on selection of studies, comparability of cohorts, and the ascertainment of either the exposure or outcome of interest [28]. Stars were awarded with highest quality studies awarded up to nine stars. Included nonrandomized studies were categorized:

- Low-quality (0 - 3 stars);

- Moderate quality (4 - 6 stars);

- High quality (7 - 9 stars).

Quality assessment of included non-comparative studies was not conducted, as these studies were assumed to be associated with high risk of bias.

\section{Statistical analysis}

Parametric data involving PIMBL, gain in alveolar ridge width, volumetric reduction of the augmented area and histomorphometric measurements are presented as mean and standard deviation (M [SD]).

\section{RESULTS \\ Study selection}

Search results are outlined in Figure 1. Electronic search resulted in 243 entries. Twenty-four additional articles were identified through hand-searching. Of these 267 articles, 91 were excluded due to being retrieved in more than one search. A total of 54 abstracts were reviewed and full-text analysis included 28 articles. Finally, one comparative [29], and 12 non-comparative studies were included [30-41].

\section{Exclusion of studies}

Reasons for excluding 15 studies after full-text assessment were: study could not be excluded before meticulous reading $(\mathrm{n}=1)$ [42], unspecified augmentation procedure $(\mathrm{n}=1)$ [43], unspecified number of implants inserted $(\mathrm{n}=1)$ [44], barrier membrane saturated in platelet-rich plasma $(\mathrm{n}=1)$ [45], immediate implant placement $(n=1)$ [46], outcome measures could not be identified for HARA in studies involving both horizontal and vertical alveolar ridge augmentation $(n=2)[47,48]$, observation period after functional loading of six months not fulfilled $(n=3)$ [49-51], or observation period not clearly specified $(n=4)[\underline{52-56}]$.

\section{Study characteristics}

Studies included in the present systematic review consisted of one comparative retrospective radiographic evaluation [29], and 12 non-comparative case-series [30-41]. Partial and totally edentulous patients with horizontal alveolar ridge deficiencies of the maxilla and mandible were enrolled. The comparative study was performed in accordance with STROBE guidelines and described power calculation of the sample size [29]. Age and gender distribution as well as inclusion criteria and exclusion criteria were specified in all included studies. Alveolar deficiency was defined according to ITItreatment guide categories [29], Cawood and Howell classification [33,37], Kennedy classification [41], or not specified [30-32, 34-36, 38-40]. Preoperative width of the alveolar ridge was specified in six noncomparative studies $[31-34, \underline{38}, \underline{39}]$. No significant difference in patient demographics was reported in the comparative study [29]. The surgical procedure was performed by the same surgeon in two studies $[\underline{37}, \underline{40}]$, by two surgeons in two studies $[\underline{36}, \underline{38}]$, and by an unknown number in eight studies $[29-35,39]$. HARA was performed under local anaesthetics in 10 studies [29-31, 33-36, 38-40], under general anaesthesia in two studies [34,37], and was not reported in one study [32]. Implant placement was performed under local anaesthesia $[\underline{29-31}, \underline{33}, \underline{35}, \underline{36-}$ 38], general anaesthesia [37], or no information was provided about the method used $[\underline{32}, \underline{34}, \underline{39}]$. FDA bone block was used in the comparative study 
(Maxgraft $^{\circledR}$ - Botiss Biomaterials GmbH; Zossen, Germany) [29], and two non-comparative studies (ReadiGraft ${ }^{\circledR}$ Canblock - LifeNet Health, Inc.; Virginia Beach, Virginia, USA) [31, 35]. DFDA bone block was used in one non-comparative study (OsteoGraft ${ }^{\circledR}$ - Argon Medical Devices Inc; Erlangen, Germany) [38]. FFA bone block from various tissue banks was used in six non-comparative studies including Clinics Hospital Tissue Bank of Universidade Federal do Parana, Curitiba, Brazil [30], Banca dei tessuti della Regione Veneto, Italy [33], Tissue Bank, Careggi Hospital, Florence, Italy [34], Gaetano Pini Orthopaedics Institute, Roma, Italy [37], Tissue Bank, Rio de Janeiro, Brazil [39], UNIOSS, Marilia, Brazil [40]. FDA bone block from Transplant Service Foundation, Sant Boi de LLobregat, Barcelona, Spain was used in one non-comparative study [36]. Origin of the used allogeneic bone block graft was not described in two non-comparative studies [32,41]. Native bone was perforated to ensure vascularization between recipient site and block graft [29-34,36-41]. Allogeneic bone block graft was covered by a barrier membrane in eight studies $[29, \underline{31}, \underline{32}, \underline{35-37}, \underline{40}, \underline{41}]$, while no membrane was used in four non-comparative studies $[\underline{33}, \underline{34}, \underline{38}, \underline{39}]$. Different implant systems were used including Biohorizons ${ }^{\circledR}$ (BioHorizons Inc; Birmingham, Alabama, USA) [36], BIOMET $3 i^{\circledR}$ (BIOMET 3i LLC; Palm Beach Gardens, Florida, USA) [29,31], blueSKYTM (bredent medical Gmbh \& Co.KG, Senden, Germany) [29], MIS implant (Mis Implant Technologies Ltd; Shlomi, Israel) [38], MIS Implant Technologies (Bar Lev Industries; Misgav, Israel) [31], Astra Tech OsseoSpeed ${ }^{\circledR}$ (Dentsply Sirona; Göteborg/Mölndal, Sweden) [33, 37$]$, Osseogrip $^{\circledR}$ (Plan 1. Health Srl; Amaro, UD, Italy) [33], PrimaConnex ${ }^{\circledR}$ (Keystone Dental, Inc.; Dallas, Texas, USA) [34], Straumann ${ }^{\circledR}$ (Straumann AG; Basal, Switzerland) $[\underline{29}, \underline{37}]$, Systhex ${ }^{\circledR}$ (Systhex Sistema de Implantes Osseointegrados Ltda; Curitiba, Brazil) [30], CM Titamax ${ }^{\circledR}$ Cortical (Neodent; Curitiba, Brazil) [40], and $\mathrm{XiVE}^{\circledR}$ (Dentsply Sirona; Göteborg/ Mölndal, Sweden) [37]. Implant system used was not specified in three non-comparative studies $[32,35,39]$. Dropouts were reported in two non-comparative studies $[\underline{33}, \underline{36]}$. None of the included studies provided information about examiner training or calibration.

\section{Data synthesis}

Meta-analyses were to be conducted only if there were studies of similar comparison, reporting identical outcome measures. However, studies included in the present systematic review revealed considerable variation in patient demographics, allogeneic bone block, barrier membrane, length of observation period, type of suprastructures and implants, dissimilar time frame between implant installation and prosthetic loading as well as different outcome measures. Therefore, a well-defined meta-analysis was not applicable.

\section{Methodological quality}

Quality of the included comparative study is summarized in Table 2.

\section{Outcome measures}

Results of HARA with allogeneic bone block compared with autogenous bone block are presented below and outlined in Table 3, followed by results of non-comparative studies in Table 4. All reported numerical values are presented as mean values. For each outcome measure, a summary is provided. Survival of suprastructures, implant stability, bone-toimplant contact and PROM were not reported in any of the included studies. Thus, these outcome measures are not described in the following section or outlined in Table 3and 4.

\section{Survival of implants \\ Comparative studies}

Survival of implants after HARA with allogeneic bone block compared with autogenous bone block from ascending mandibular ramus was $100 \%$ for both treatment modalities, after 12 months [29].

\section{Non-comparative studies}

Survival of implants after HARA with allogeneic bone block varied between $90 \%$ and $100 \%$, after 12 to 82 months [이-41].

Table 2. Newcastle-Ottawa scale for assessing quality of non-randomized studies [28], categorized as low-quality ( 0 - 3 stars), moderate quality ( 4 - 6 stars), and high quality ( 7 - 9 stars)

\begin{tabular}{c|c|c|c|c|c}
\hline Study & $\begin{array}{c}\text { Year of } \\
\text { publication }\end{array}$ & $\begin{array}{c}\text { Selection } \\
\text { (maximum 4 stars) }\end{array}$ & $\begin{array}{c}\text { Comparability } \\
\text { (maximum 2 stars) }\end{array}$ & $\begin{array}{c}\text { Outcome } \\
\text { (maximum 3 stars) }\end{array}$ & $\begin{array}{c}\text { Total score/ } \\
\text { quality }\end{array}$ \\
\hline Kloss et al. [29] & 2018 & $\star \star \star \star$ & $\star \star$ & $\star \star \star$ & $\begin{array}{c}8 \text { stars/ } \\
\text { high quality }\end{array}$ \\
\hline
\end{tabular}


Table 3. Horizontal alveolar ridge augmentation with allogeneic bone block graft compared with autogenous bone block graft

\begin{tabular}{|c|c|c|c|c|c|c|c|c|c|c|c|c|c|c|c|}
\hline \multirow{4}{*}{ Study } & \multirow{4}{*}{$\begin{array}{l}\text { Study } \\
\text { design }\end{array}$} & \multicolumn{14}{|c|}{ Outcome measures } \\
\hline & & \multirow{3}{*}{ Patients } & \multirow{3}{*}{$\begin{array}{l}\text { ARW } \\
(\mathrm{mm})\end{array}$} & \multirow{3}{*}{ Site } & \multirow{3}{*}{ Graft/N } & \multirow{3}{*}{$\begin{array}{c}\text { GH } \\
\text { (months) }\end{array}$} & \multirow{3}{*}{ Implant } & \multirow{3}{*}{$\begin{array}{c}\text { IH } \\
\text { (months) }\end{array}$} & \multirow{3}{*}{ Prosthetics } & \multirow{3}{*}{$\begin{array}{c}\text { OP } \\
\text { (months) }\end{array}$} & \multirow{3}{*}{$\begin{array}{c}\text { Implant } \\
\text { survival } \\
(\%)\end{array}$} & \multicolumn{3}{|c|}{$\begin{array}{c}\text { GARW (mm)/ } \\
\text { VRAA }(\%)\end{array}$} & \multirow{3}{*}{ BCT } \\
\hline & & & & & & & & & & & & PO & 6 months & 12 months & \\
\hline & & & & & & & & & & & & Mean (SD) & Mean (SD) & Mean (SD) & \\
\hline \multirow{2}{*}{ Kloss et al. [29] } & \multirow{2}{*}{$\begin{array}{l}\text { Retrospective } \\
\text { study }\end{array}$} & 21 & \multirow{2}{*}{ NR } & \multirow{2}{*}{ NR } & $\begin{array}{l}\text { Mandible } \\
\text { ramus: } 21\end{array}$ & \multirow{2}{*}{6} & 21 & \multirow{2}{*}{6} & \multirow{2}{*}{ Single-crown } & \multirow{2}{*}{6} & \multirow{2}{*}{100} & $5.6(1.5)$ & $5.2(1.6) / 5.3(6.2)$ & $5.1(1.5) / 6.3(6.2)$ & \multirow{2}{*}{ None } \\
\hline & & 21 & & & \begin{tabular}{|l|} 
FDA: 21 \\
\end{tabular} & & 21 & & & & & $5.5(1.5)$ & $5.2(1.4) / 4.4(7.1)$ & \begin{tabular}{|l|}
$5.2(1.4) / 4.8(7.2)$ \\
\end{tabular} & \\
\hline
\end{tabular}

$\mathrm{ARW}=$ alveolar ridge width; $\mathrm{BTC}=$ biological and technical complications; $\mathrm{FDA}=$ freeze-dried bone allograft; $\mathrm{GARW}=$ gain in alveolar ridge width; $\mathrm{GH}=$ graft healing time; $\mathrm{IH}=$ implant healing time; $\mathrm{N}=$ number; $\mathrm{NR}=$ no reported; $\mathrm{OP}=$ observation period after functional implant loading; $\mathrm{PO}=$ postoperative; $\mathrm{VRAA}=$ volumetric reduction of the augmented area; $\mathrm{SD}=$ standard deviation.

Table 4. Horizontal alveolar ridge augmentation with allogeneic bone block graf

\begin{tabular}{|c|c|c|c|c|c|c|c|c|c|c|c|c|c|c|c|c|c|c|c|}
\hline \multirow[b]{2}{*}{ Study } & \multirow{2}{*}{$\begin{array}{c}\text { Year of } \\
\text { publication }\end{array}$} & \multirow{2}{*}{$\begin{array}{l}\text { Study } \\
\text { design }\end{array}$} & \multicolumn{17}{|c|}{ Outcome measures } \\
\hline & & & Patients & $\begin{array}{l}\text { ARW } \\
(\mathrm{mm})\end{array}$ & Site & Graft/N & $\begin{array}{c}\text { GH } \\
\text { (months) }\end{array}$ & Implant & $\begin{array}{c}\text { IH } \\
\text { (months) }\end{array}$ & Prosthetics & \begin{tabular}{c|}
$\begin{array}{c}\text { OP } \\
\text { (months) }\end{array}$ \\
\end{tabular} & $\begin{array}{l}\text { IS } \\
(\%)\end{array}$ & \multicolumn{2}{|c|}{$\begin{array}{l}\text { PIMBL } \\
(\mathrm{mm})\end{array}$} & \multicolumn{3}{|c|}{$\begin{array}{l}\text { Histomorphometric } \\
\text { measurements (\%) }\end{array}$} & $\begin{array}{l}\text { GAW (mm)/ } \\
\text { VRAA (\%) }\end{array}$ & BTC \\
\hline Contar et al. [30] & 2009 & $\mathrm{CS}$ & 15 & NR & Maxil & FFA: 34 & $9(8-11)$ & 51 & NR & NR & $24-35$ & 100 & \multicolumn{2}{|c|}{ NR } & \multicolumn{3}{|c|}{ NR } & NR & GE: 1 \\
\hline \multirow{2}{*}{ Nissan et al. [31] } & \multirow{2}{*}{2011} & \multirow{2}{*}{ CS } & \multirow{2}{*}{12} & \multirow{2}{*}{$\leq 3$} & \multirow{2}{*}{ Maxil mandible } & \multirow{2}{*}{ FDA: 19} & \multirow{2}{*}{6} & \multirow{2}{*}{21} & \multirow{2}{*}{$0-6$} & \multirow{2}{*}{ Fixed prosthesis } & \multirow{2}{*}{$13-60$} & \multirow{2}{*}{95.2} & \multirow{2}{*}{\multicolumn{2}{|c|}{$\begin{array}{l}\text { No crestal bone loss } \\
\text { beyond first thread }\end{array}$}} & \multirow{2}{*}{\multicolumn{3}{|c|}{ NR }} & 6 months & \multirow{2}{*}{$\begin{array}{l}\text { GE: } 4 \\
\text { Fistula: } 1\end{array}$} \\
\hline & & & & & & & & & & & & & & & & & & $5(\mathrm{SD} 0.5)$ & \\
\hline \multirow{3}{*}{ Nissan et al. [32] } & & & & & & & & & & & & & & & & 6 months & & 6 months & \\
\hline & 2011 & $\mathrm{CS}$ & 24 & $\leq 3$ & Mandible & FDA: 34 & 6 & 85 & 3 & Fixed prosthesis & $12-66$ & 95.3 & $\mathrm{~N}$ & $\mathrm{R}$ & NBF & $\mathrm{RG}$ & CT & $56(\mathrm{SD} 1) / 5$ & NR \\
\hline & & & & & & & & & & & & & & & 40 (SD 28) & 29 (SD 24) & 27 (SD 21) & $5.0(\mathrm{SD} 1) / 5$ & \\
\hline Orsini et al [33] & 2011 & $C S_{S}$ & 10 & $15-28$ & Moxil & FFA. 10 & 5 & 14 & 5 & Single crowns & 24 & 100 & & & & 6 months & & 5 months & TGL 1 \\
\hline ] & 2011 & Ca & 10 & $1.5-2.0$ & Niasin & ТTA. IO & 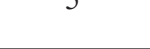 & 14 & 3 & Dilge Ciowis & 24 & 100 & & & NBF & $58(\mathrm{SI}$ & 25) & $4.6(\mathrm{SD} 0.5)$ & IGL: 1 \\
\hline & & & & & & & & & & & & & & & & & & 4- 9 months & \\
\hline Acocella et al. [34] & 2012 & CS & 16 & $2-4$ & Maxil & FFA: 18 & $4-9$ & 34 & 4 & Fixed prosthesis & $18-30$ & 100 & $\mathrm{~N}$ & & Non-vi & tal bone: 62 (S & D 12) & $\begin{array}{l}4.1(\mathrm{SD} 0.8) / \\
11.5(0-30)\end{array}$ & GE: 1 \\
\hline & & & & & & & & & & & & & & & & 6 months & & & \\
\hline Nissen et al. [35] & 2012 & CS & 40 & $\leq 3$ & Maxil & FDA: 60 & 6 & 83 & 3 & Fixed prosthesis & $14-82$ & 98.8 & $\mathrm{~N}$ & R & NBF & RG & CT & $\mathrm{NR}$ & DH: 16 \\
\hline & & & & & & & & & & & & & & & 33 (SD 18) & 26 (SD 17) & 41 (SD 2) & & \\
\hline Novell et al. [36] & 2012 & CS & 15 & NR & Maxil mandible & FDA: 36 & $4-6$ & 53 & $4-6$ & NR & $12-60$ & 100 & $\mathrm{~N}$ & R & & NR & & NR & $\begin{array}{l}\text { GE: } 1 \\
\text { FG: } 1\end{array}$ \\
\hline & & & & & & & $5=7$ & 117 & 5 & & & & 12 months & 24 months & & & & & $\begin{array}{l}\text { DH: } 14 \\
\text { PGI }\end{array}$ \\
\hline Chiapasco et al. [37] & 2015 & $\mathrm{CS}$ & 19 & $\leq 3$ & Maxil mandible & FFA: NR & $5-7$ & 117 & $5-6$ & NR & $20-32$ & 90.2 & 1.6 (SD 1.6) & 1.9 (SD 1.4) & & NR & & NR & $\begin{array}{l}\text { PGL: } 5 \\
\text { TGL: } 2\end{array}$ \\
\hline & & & & & & & & & & & & & & & & 5 months & & 5 months & \\
\hline Aslan et al. [38] & 2016 & $\mathrm{CS}$ & 11 & $<5$ & Maxil mandible & DFDA: 12 & 5 & 32 & 3 & Fixed prosthesis & 24 & 100 & $\mathrm{~N}$ & $\mathrm{R}$ & NBF & RG & CT & & None \\
\hline & & & & & & & & & & & & & & & 40 (SD 25) & 40 (SD 21) & 19 (SD 15) & $1.7(\mathrm{SD} 0.1) / 5.4$ & \\
\hline Deluiz et al. [39] & 2016 & CS & 8 & NR & Maxil & FFA: NR & $4-6$ & 268 & 4 & Fixed prosthesis & 12 & 94 & $\mathrm{~N}$ & $\mathrm{R}$ & & NR & & NR & $\begin{array}{l}\text { DH: } 5 \\
\text { PGL: } 4 \\
\text { TGL: } 3\end{array}$ \\
\hline & & & & & & & & & & & & & & & & 6 months & & 12 months & \\
\hline Silva et al. [40] & 2017 & CS & 20 & $\leq 6$ & Mandible & FFA: 50 & 6 & 50 & 6 & Single-crown & $20-42$ & 96 & $\mathrm{~N}$ & $\mathrm{R}$ & NBF & RG & CT & 1(SD 0 7)/41 & GE: 6 \\
\hline & & & & & & & & & & & & & & & 32 (SD 1) & 15 (SD 0) & 54 (SD 1) & $4(3 D 0 . /) / 41$ & \\
\hline & & & & & & & & & & & & & & & & 6 months & & & \\
\hline Chaushu et al. [41] & 2019 & CS & 14 & NR & Mandible & NR: 24 & 6 & 26 & 3 & $\begin{array}{l}\text { Mostly fixed } \\
\text { nrothesis }\end{array}$ & $12-54$ & 100 & No crestal & bone loss & $\mathrm{NBF}$ & RG & CT & $5(\mathrm{SD} 0.5)$ & TGL: 2 \\
\hline & & & & & & & & & & & & & & & 42 & 17 & 41 & & PGL: 6 \\
\hline
\end{tabular}

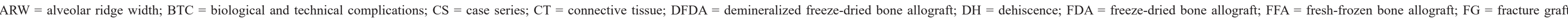

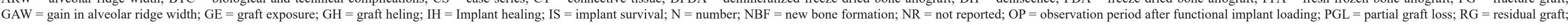

$\mathrm{TGL}=$ total graft loss; $\mathrm{VRAA}=$ volumetric reduction of the augmented area; $\mathrm{SD}=$ standard deviation . 


\section{Summary}

The comparative study revealed high short-term implant survival with both treatment modalities. Non-comparative studies disclosed high long-term implant survival after HARA with allogeneic bone block.

\section{Peri-implant marginal bone loss Non-comparative studies}

PIMBL was $1.2 \mathrm{~mm}$ at implant loading increasing to 1.6 and $1.9 \mathrm{~mm}$, one year and two years after implant loading, respectively [37]. No crestal bone loss beyond the first implant thread was reported in two studies, after an observation period between 12 to 60 months $[\underline{31}, \underline{41}]$.

\section{Summary}

PIMBL after HARA with allogeneic bone block was estimated in one non-comparative study demonstrating a PIMBL of $1.9 \mathrm{~mm}$, after two years of implant loading.

\section{Histomorphometric measurements Non-comparative studies}

Histomorphometric analysis of bone samples after HARA with FDA revealed 33 to $40 \%$ new bone formation, 26 to $40 \%$ residual graft material and 19 to $41 \%$ connective tissue, after six months $[\underline{32}, \underline{35}]$. DFDA showed $40 \%$ new bone formation, $40 \%$ residual graft material and $19 \%$ connective tissue, after five months [38]. FFA disclosed 32 to $58 \%$ new bone formation, $15 \%$ residual graft material and $54 \%$ connective tissue, after six months $[\underline{33}, \underline{40}]$. Non-vital bone volume after HARA with FFA was $62 \%$, after four to nine months [34].

\section{Summary}

HARA with allogeneic bone block facilitated bone regeneration and new bone formation in noncomparative studies. However, a high percentage of non-vital bone volume was reported after HARA with FFA.

Gain in alveolar ridge width and volumetric reduction of the augmented area Comparative studies

Gain in alveolar ridge width was $5.5 \mathrm{~mm}$ immediately after HARA with allogeneic bone block and $5.6 \mathrm{~mm}$ with autogenous bone block [29]. Corresponding measurements after six and 12 months were 5.2 and $5.2 \mathrm{~mm}$ with allogeneic bone block and 5.2 and 5.1 $\mathrm{mm}$ with autogenous bone block, respectively. There was no statistically significant difference in gain in alveolar ridge width between the two treatment modalities at any time points [29].

HARA with allogeneic bone block revealed 4.4\% and $4.8 \%$ volumetric reduction of the augmented area after six and twelve months, respectively [29]. Corresponding measurements for autogenous bone block were $5.3 \%$ and $6.3 \%$. There was no statistically significant difference in volumetric reduction of the augmented area between the treatment modalities at any time points [29].

\section{Non-comparative studies}

Gain in alveolar ridge width was $5 \mathrm{~mm}$ after HARA with FDA, after six months [31]. Gain in alveolar ridge width was estimated by subtracting the initial clinical width of the alveolar ridge from clinical width at time of implant placement [31].

Gain in alveolar ridge width was $5.6 \mathrm{~mm}$ after HARA with FDA, after six months [32]. Method and location used in estimating gain in alveolar ridge width was not specified. A $5 \%$ volumetric reduction of the augmented area was observed, six months after HARA [32].

Gain in alveolar ridge width was $4.6 \mathrm{~mm}$ after HARA with FFA, after five months [33]. Gain in alveolar ridge width was measured with computed tomography by subtracting initial width of the alveolar ridge from width at time of implant placement [33].

Immediate gain in alveolar ridge width after HARA with FFA was 4.6 and $4.1 \mathrm{~mm}$, after four to nine months [34]. Gain in alveolar ridge width was measured with calipers by subtracting initial width of the alveolar ridge from width at time of HARA and implant placement. A $11.5 \%$ volumetric reduction of the augmented area was observed, four to nine months after HARA [34].

Immediate gain in alveolar ridge width after HARA with FFA was $6.4 \mathrm{~mm}$ [을. Corresponding measurements after six months and twelve months was 4.6 and $4 \mathrm{~mm}$, respectively. Gain in alveolar ridge width was measured on cone beam computed tomography using linear measurements from head of the fixation screw as reference point by subtracting initial width of alveolar ridge from width at time of HARA, implant placement, and twelve months after functional implant loading. A 31\% volumetric reduction of the augmented area was observed, after 
six months, and an additional $10 \%$ after twelve months, respectively [40].

\section{Summary}

The comparative study disclosed no statistically significant difference in gain in alveolar ridge width and volumetric reduction of augmented area between the treatment modalities. Non-comparative short-term studies demonstrated gain in alveolar ridge width of 5 to $5.6 \mathrm{~mm}$ after HARA with FDA, and $4.6 \mathrm{~mm}$ with FFA. Substantial volumetric stability of the augmented area for implant placement was revealed in most of the non-comparative studies.

\section{Biologic and technical complications Comparative studies}

No signs of infection, wound dehiscence, graft exposure, or other biologic and technical complications were reported with both treatment modalities [29].

\section{Non-comparative studies}

No biologic or technical complications were reported in one study [38]. Postoperative pain, oedema, bruising and haematomas have been described after HARA with allogeneic bone block $[\underline{30}, \underline{37}, \underline{38}]$. Soft tissue dehiscence has been reported in three studies with incidence varying between $27 \%$ and $74 \%$ [3537], while incision line opening occurred in $80 \%$ [41]. Graft exposure has been reported in seven studies with incidence varying between $6 \%$ and $74 \%[\underline{30}, \underline{31}, \underline{34}, \underline{36}, \underline{37}, \underline{40}, \underline{41}]$. Partial or total loss of allogeneic bone block caused by infection and/ or graft exposure have been reported in four studies $[33,37,39,41]$. Moreover, soft tissue dehiscence, graft exposure and loss of graft after implant placement and abutment connection was frequently observed in one study [37]. A statistically significant correlation between infection and graft loss was reported in one study [39]. Fracture of the allogeneic bone block was reported in one study [36].

Fistula in the marginal gingiva after crown cementation was described in one patient [31]. The fistula closed spontaneously after curettage in the gingival sulcus [피]

\section{Summary}

Frequency of short-term and long-term biologic complications including incision line opening, soft tissue dehiscence, graft exposure and partial or total loss of allogeneic bone block was high. Consequently, increased risk of biologic complications may compromise long-term implant survival after HARA with allogeneic bone block.

\section{DISCUSSION}

The objective of the present systematic review was to test the hypothesis of no difference in implant treatment outcome after HARA with allogeneic bone block compared with autogenous bone block. One comparative retrospective study with high quality [29], and 12 non-comparative studies [30-41] fulfilled inclusion criteria. Considerable heterogeneity among included studies prevented meta-analysis performance. Moreover, diversity of evaluation methods, dissimilar observation periods after implant loading and various methodological confounding factors posed serious restrictions to literature review in a quantitative systematic manner. Hence, conclusions drawn from the results of the present systematic review should be interpreted with caution.

Survival of suprastructures and implants are the most important measures for assessment of longterm implant treatment outcomes. However, survival of suprastructure was not reported in any of the included studies. Survival of implant was reported in all included studies, but long-term studies assessing implant survival after HARA with allogeneic bone block compared with autogenous bone block is lacking. Long-term studies assessing HARA with autogenous bone block have demonstrated implant survival of $95.7 \%$ and $98.1 \%$, after 10 years [ㅈ, 7$]$. A non-comparative long-term study included in the present systematic review disclosed implant survival of $98.8 \%$, after 14 to 82 months [35]. Consequently, long-term randomized controlled trials assessing survival of suprastructures and implants after HARA with allogeneic bone block compared with autogenous bone block are needed before one treatment modality may be considered superior to another.

A newly published systematic review and metaanalysis concluded that HARA maintains peri-implant health over time with low mucosal inflammatory changes and relatively small incidence of PIMBL [57], in accordance with previously published systematic reviews $[\underline{58}, \underline{59}]$. A criterion of successful implant treatment is PIMBL of less than 1 to $1.5 \mathrm{~mm}$ during the first year after implant loading and less than $0.2 \mathrm{~mm}$ annually, which in turn corresponds to a maximum of $1.7 \mathrm{~mm}$ after two years and $3.3 \mathrm{~mm}$ after 10 years $[\underline{60}, 61]$. PIMBL was estimated in one noncomparative study demonstrating $1.6 \mathrm{~mm}$ PIMBL, 
one year after implant loading increasing to $1.9 \mathrm{~mm}$ after two years, which is larger than the described implant success criterion [37]. Long-term studies assessing HARA with autogenous bone block have demonstrated limited PIMBL, in accordance with the success criterion [, 7 ] $]$. A comparative study assessing horizontal and vertical augmentation of extremely atrophic edentulous maxilla's with allogeneic bone block disclosed a statistically significant larger PIMBL with allogeneic bone block compared with autogenous bone block [47]. Allogeneic bone block disclosed $1.5 \mathrm{~mm}$ and $1.6 \mathrm{~mm}$ PIMBL, one and two years after implant loading, respectively. Corresponding measurements for autogenous bone block was $0.8 \mathrm{~mm}$ and $0.9 \mathrm{~mm}$, respectively [47]. Consequently, HARA with allogeneic bone block seems to be associated with higher risk of PIMBL compared with autogenous bone block. However, long-term randomized controlled trials are needed to validate this assumption.

A recent systematic review assessing the efficacy of various grafting materials in alveolar ridge augmentation demonstrated that the degree of bone formation within the grafted volume was 33\% with allogeneic bone graft compared with $51 \%$ for autogenous bone graft, and $56 \%$ for mixtures of autogenous bone graft and other grafting materials [3]. The non-comparative studies revealed $32 \%$ to $58 \%$ new bone formation after HARA with allogeneic bone block $[\underline{32}, \underline{33}, \underline{35}, \underline{38}, \underline{40}]$. A randomized controlled trial assessing HARA with FFA demonstrated no statistically significant differences in calcified tissue, new bone formation and remaining graft material after four months compared with six months, indicating no beneficial effect of a healing period longer than four months prior to implant placement [56]. Amount of bone regeneration after HARA with allogeneic bone block compared with autogenous bone block has been previously assessed in controlled trials $[\underline{19}, \underline{62}]$, and randomized controlled trials [20]. A statistically significant larger amount of vital bone was revealed after HARA with autogenous bone block compared with FFA, after six to eight months [19]. However, histomorphometric analysis of bone samples obtained after HARA with FFA revealed no statistically significant difference in percentage of lamellar bone and new bone formation compared with autogenous bone block, after seven to nine months [62]. Qualitative histologic analysis of biopsies obtained from allogeneic bone block frequently showed areas of non-viable bone, with empty lacunae and poor bone remodelling in the most distant portions from the recipient bed [62]. These results are in accordance with a non-comparative study of the present systematic review disclosing $62 \%$ non-vital bone volume after HARA with FFA [34]. Moreover, a randomized controlled trial assessing HARA with FFA compared with autogenous bone block revealed new bone formation with both treatment modalities, but FFA demonstrated clear signs of inflammation [20]. Similar healing patterns have been observed in an experimental study demonstrating statistically significant greater revascularization and bony replacement after HARA with autogenous bone block compared with allogeneic bone block [63]. Autogenous bone block was replaced by newly formed bone, whereas regions of non-vital bone were seen after HARA with allogeneic bone block [63]. Consequently, both treatment modalities seem to facilitate new bone formation. However, amount of bone regeneration after HARA with autogenous bone block seems to be enhanced compared with allogeneic bone block.

HARA with use of a block graft is considered a highly predictable surgical technique for obtaining sufficient bone volume for delayed implant placement $[\underline{3-5}, 9, \underline{10}]$. Gain in alveolar ridge width of more than $4 \mathrm{~mm}$ after HARA with autogenous bone block has previously been documented $[4,64,65]$. The comparative study of the present systematic review revealed equivalent gain in alveolar ridge width and volumetric stability of augmented areas with allogeneic bone block compared with autogenous bone block [29]. Most of the included noncomparative studies revealed similar gain in alveolar ridge width and volumetric stability of the augmented area $[\underline{31-34}, \underline{38}, \underline{41}]$. However, continued reduction of the augmented area was reported in one of the included non-comparative studies [40], in accordance with a randomized controlled trial measuring graft resorption at different time points after HARA with allogeneic bone block [50]. Computed tomography and three-dimensional measurements demonstrated mean graft resorption of $13 \%$ after four months, $33 \%$ after six months, and $51 \%$ after eight months, respectively [50]. Moreover, randomized controlled trials using computed tomography and threedimensional measurements have shown statistically significant larger volumetric reduction of the augmented area after HARA with FFA compared with autogenous bone block $[\underline{20}, \underline{21}]$. In conclusion, HARA with allogeneic bone block seems to gain sufficient alveolar ridge width for delayed implant placement, but an unpredictable volumetric reduction of the augmented area evidently occurs during the healing phase. Studies included in the present systematic review used dissimilar clinical and radiographic twodimensional linear measurements for assessment 
of gain in alveolar ridge width and volumetric reduction of the augmented area, which certainly incorporates measurements error. A bone block is an inhomogeneous and three-dimensional anisotropic structure and, therefore three-dimensional methods should be applied for studies assessing volumetric reduction of the augmented area. Therefore, conclusions of the present systematic review may be compromised by use of different measurement techniques and observation periods. Thus, further long-term randomized controlled trails should use standardized methods and three-dimensional volumetric measurements.

Biologic complications including soft tissue dehiscence, graft exposure, partial and total graft loss have been reported in a systematic review after HARA with autogenous bone block [59]. Moreover, temporary and permanent paraesthesia as well as gait disturbances have been described after harvesting autogenous bone graft in conjunction with HARA $[\underline{47}, 62,66]$. No biologic or technical complications were reported in the comparative study of the present systematic review [29]. However, a previous published study assessing HARA with allogeneic bone block reported dehiscence and graft exposure as well as partial and total loss of graft before and after implant placement compared with no complications after HARA with autogenous bone block [62] Likewise, graft exposure and loss have been described after HARA with allogeneic bone block compared with no biologic complications with autogenous bone block [67]. High incidence of biologic complications including incision line opening, soft tissue dehiscence, graft exposure, partial or total loss of the allogeneic bone block were reported in some included noncomparative studies $[31,37, \underline{39-41]}$ of the present systematic review. Similar observations have been described after HARA with allogeneic bone block $[\underline{45}, \underline{48}, \underline{49}]$. Moreover, a comparative study assessing horizontal and vertical augmentation of extremely atrophic edentulous maxilla's with allogeneic bone block graft disclosed increased soft tissue dehiscence, graft exposure and sequestration before and after implant placement with allogeneic bone block compared with autogenous bone block from the iliac crest [47]. Hence, HARA with allogeneic bone block seems to be associated with increased risk of biologic complications at the recipient site, which may compromise long-term implant survival.

Allogeneic bone block use for HARA compared with harvesting autogenous bone block is associated with obvious advantages for patients. Consequently, comparison of the two treatment modalities should contain evaluation of donor site morbidity, inflammatory reactions, economic perspective, PROM and length of patient treatment time. However, these aspects have not been addressed in any of the included studies.

\section{CONCLUSIONS}

The hypothesis of no difference in implant treatment outcome after horizontal alveolar ridge augmentation with allogeneic bone block compared with autogenous bone block could neither be confirmed nor rejected due to insufficient available knowledge. A comparative retrospective shortterm study revealed no statistically significant difference in implant treatment outcome between the two treatment modalities. Non-comparative longterm studies demonstrated high implant survival, gain in alveolar ridge width and bone regeneration after horizontal alveolar ridge augmentation with allogeneic bone block. However, high incidence of biologic complications including soft tissue dehiscence, exposure of allogeneic bone block, partial or total loss of the block graft were reported in noncomparative studies. Moreover, dissimilar evaluation methods, observation periods, outcome measures and various methodological confounding factors posed serious restrictions for literature review in a quantitative systematic manner. Hence, conclusions drawn from results of this systematic review should be interpreted with caution and further long-term randomized controlled trials including assessment of donor site morbidity, patient-reported outcome measures, economic perspective and patient treatment time are needed before definite conclusions can be provided about horizontal alveolar ridge augmentation with allogeneic bone block compared with autogenous bone block.

\section{ACKNOWLEDGMENTS AND DISCLOSURE STATEMENTS}

The authors declare that there are no financial or other conflicts of interest related to this publication.

There were no sources of funding for this systematic review.

No funding has been received for the present study. 


\section{REFERENCES}

1. Tan WL, Wong TL, Wong MC, Lang NP. A systematic review of post-extractional alveolar hard and soft tissue dimensional changes in humans. Clin Oral Implants Res. 2012 Feb;23 Suppl 5:1-21. [Medline: 22211303] [doi: $10.1111 / \mathrm{j} .1600-0501.2011 .02375 . \mathrm{x}]$

2. Aludden HC, Mordenfeld A, Hallman M, Dahlin C, Jensen T. Lateral ridge augmentation with Bio-Oss alone or BioOss mixed with particulate autogenous bone graft: a systematic review. Int J Oral Maxillofac Surg. 2017 Aug;46(8): 1030-1038. [Medline: 28366452] [doi: 10.1016/j.ijom.2017.03.008]

3. Troeltzsch M, Troeltzsch M, Kauffmann P, Gruber R, Brockmeyer P, Moser N, Rau A, Schliephake H. Clinical efficacy of grafting materials in alveolar ridge augmentation: A systematic review. J Craniomaxillofac Surg. 2016 Oct;44(10): 1618-1629. [Medline: 27622971] [doi: 10.1016/j.jcms.2016.07.028]

4. Sanz-Sánchez I, Ortiz-Vigón A, Sanz-Martín I, Figuero E, Sanz M. Effectiveness of Lateral Bone Augmentation on the Alveolar Crest Dimension: A Systematic Review and Meta-analysis. J Dent Res. 2015 Sep;94(9 Suppl):128S-42S. [Medline: 26215467] [doi: 10.1177/0022034515594780]

5. Kuchler U, von Arx T. Horizontal ridge augmentation in conjunction with or prior to implant placement in the anterior maxilla: a systematic review. Int J Oral Maxillofac Implants. 2014;29 Suppl:14-24. [Medline: 24660187] [doi: 10.11607/jomi.2014suppl.g1.1]

6. Chappuis V, Cavusoglu Y, Buser D, von Arx T. Lateral Ridge Augmentation Using Autogenous Block Grafts and Guided Bone Regeneration: A 10-Year Prospective Case Series Study. Clin Implant Dent Relat Res. 2017 Feb;19(1):85-96. [Medline: 27476677] [doi: 10.1111/cid.12438]

7. Meijndert CM, Raghoebar GM, Meijndert L, Stellingsma K, Vissink A, Meijer HJ. Single implants in the aesthetic region preceded by local ridge augmentation; a 10-year randomized controlled trial. Clin Oral Implants Res. 2017 Apr;28(4): 388-395. [Medline: 26919705] [doi: 10.1111/clr.12811]

8. Verdugo F, Uribarri A, D'Addona A. Autogenous bone block grafting provides facial implant tissue stability long-term. Clin Implant Dent Relat Res. 2017 Jun;19(3):478-485. [Medline: 28185382] [doi: 10.1111/cid.12476]

9. Fuglsig JMCES, Thorn JJ, Ingerslev J, Wenzel A, Spin-Neto R. Long term follow-up of titanium implants installed in block-grafted areas: A systematic review. Clin Implant Dent Relat Res. 2018 Dec;20(6):1036-1046. [Medline: 30238612] [doi: $10.1111 / \mathrm{cid} .12678$ ]

10. Esposito M, Grusovin MG, Felice P, Karatzopoulos G, Worthington HV, Coulthard P. The efficacy of horizontal and vertical bone augmentation procedures for dental implants - a Cochrane systematic review. Eur J Oral Implantol. 2009 Autumn;2(3):167-84. [Medline: 20467628]

11. Nkenke E, Neukam FW. Autogenous bone harvesting and grafting in advanced jaw resorption: morbidity, resorption and implant survival. Eur J Oral Implantol. 2014 Summer;7 Suppl 2:S203-17. [Medline: 24977256]

12. Jensen T, Schou S, Svendsen PA, Forman JL, Gundersen HJ, Terheyden H, Holmstrup P. Volumetric changes of the graft after maxillary sinus floor augmentation with Bio-Oss and autogenous bone in different ratios: a radiographic study in minipigs. Clin Oral Implants Res. 2012 Aug;23(8):902-10. [Medline: 22044477] [doi: 10.1111/j.1600-0501.2011.02245.x]

13. Cricchio G, Lundgren S. Donor site morbidity in two different approaches to anterior iliac crest bone harvesting. Clin Implant Dent Relat Res. 2003;5(3):161-9. [Medline: 14575632] [doi: 10.1111/j.1708-8208.2003.tb00198.x]

14. Danesh-Sani SA, Engebretson SP, Janal MN. Histomorphometric results of different grafting materials and effect of healing time on bone maturation after sinus floor augmentation: a systematic review and meta-analysis. J Periodontal Res. 2017 Jun;52(3):301-312. [Medline: 27534916] [doi: 10.1111/jre.12402]

15. Avila-Ortiz G, Chambrone L, Vignoletti F. Effect of alveolar ridge preservation interventions following tooth extraction: A systematic review and meta-analysis. J Clin Periodontol. 2019 Jun;46 Suppl 21:195-223. [Medline: 30623987] [doi: 10.1111 jicpe.13057]

16. Chavda S, Levin L. Human Studies of Vertical and Horizontal Alveolar Ridge Augmentation Comparing Different Types of Bone Graft Materials: A Systematic Review. J Oral Implantol. 2018 Feb;44(1):74-84. [Medline: 29135351] [doi: 10.1563/aaid-joi-D-17-00053]

17. Motamedian SR, Khojaste M, Khojasteh A. Success rate of implants placed in autogenous bone blocks versus allogenic bone blocks: A systematic literature review. Ann Maxillofac Surg. 2016 Jan-Jun;6(1):78-90. [Medline: 27563613] [PMC free article: 4979349] [doi: 10.4103/2231-0746.186143]

18. Waasdorp J, Reynolds MA. Allogeneic bone onlay grafts for alveolar ridge augmentation: a systematic review. Int J Oral Maxillofac Implants. 2010 May-Jun;25(3):525-31. [Medline: 20556251]

19. Spin-Neto R, Stavropoulos A, Coletti FL, Pereira LA, Marcantonio E Jr, Wenzel A. Remodeling of cortical and corticocancellous fresh-frozen allogeneic block bone grafts--a radiographic and histomorphometric comparison to autologous bone grafts. Clin Oral Implants Res. 2015 Jul;26(7):747-52. [Medline: 24953889] [doi: 10.1111/clr.12343]

20. Lumetti S, Consolo U, Galli C, Multinu A, Piersanti L, Bellini P, Manfredi E, Corinaldesi G, Zaffe D, Macaluso GM, Marchetti C. Fresh-frozen bone blocks for horizontal ridge augmentation in the upper maxilla: 6-month outcomes of a randomized controlled trial. Clin Implant Dent Relat Res. 2014 Feb;16(1):116-23. [Medline: 22530793] [doi: $10.1111 / \mathrm{j} .1708-8208.2012 .00458 . x$ ] 
21. Lumetti S, Galli C, Manfredi E, Consolo U, Marchetti C, Ghiacci G, Toffoli A, Bonanini M, Salgarelli A, Macaluso GM. Correlation between density and resorption of fresh-frozen and autogenous bone grafts. Biomed Res Int. 2014;2014:508328. [Medline: 25050354] [PMC free article: 4094706] [doi: 10.1155/2014/508328]

22. Spin-Neto R, Stavropoulos A, Dias Pereira LA, Marcantonio E Jr, Wenzel A. Fate of autologous and fresh-frozen allogeneic block bone grafts used for ridge augmentation. A CBCT-based analysis. Clin Oral Implants Res. 2013 Feb;24(2):167-73. [Medline: 22093001] [doi: 10.1111/j.1600-0501.2011.02324.x]

23. Spin-Neto R, Landazuri Del Barrio RA, Pereira LA, Marcantonio RA, Marcantonio E, Marcantonio E Jr. Clinical similarities and histological diversity comparing fresh frozen onlay bone blocks allografts and autografts in human maxillary reconstruction. Clin Implant Dent Relat Res. 2013 Aug;15(4):490-7. [Medline: 21834864] [doi: 10.1111/j.1708-8208.2011.00382.x]

24. da Costa CE, Pelegrine AA, Fagundes DJ, Simoes Mde J, Taha MO. Use of corticocancellous allogeneic bone blocks impregnated with bone marrow aspirate: a clinical, tomographic, and histomorphometric study. Gen Dent. 2011 Sep-Oct;59(5):e200-5. [Medline: 22313831]

25. Welch V, Petticrew M, Tugwell P, Moher D, O’Neill J, Waters E, White H; PRISMA-Equity Bellagio group. PRISMAEquity 2012 extension: reporting guidelines for systematic reviews with a focus on health equity. PLoS Med. 2012;9(10):e1001333. [Medline: 23222917] [PMC free article: 3484052] [doi: 10.1371/journal.pmed.1001333]

26. Higgins JPT, Altman DG, Sterne JAC. Chapter 8: assessing risk of bias in included studies. In: Higgins JPT, Green S, editors. Cochrane handbook for systematic reviews of interventions version 5.1.0 (updated March 2011). The Cochrane Collaboration. 2011. [URL: http://handbook.cochrane.org/]

27. Higgins JP, Altman DG, Gøtzsche PC, Jüni P, Moher D, Oxman AD, Savovic J, Schulz KF, Weeks L, Sterne JA; Cochrane Bias Methods Group; Cochrane Statistical Methods Group. The Cochrane Collaboration's tool for assessing risk of bias in randomised trials. BMJ. 2011 Oct 18;343:d5928. [Medline: 22008217] [PMC free article: 3196245] [doi: 10.1136/bmj.d5928]

28. Wells GA, Shea B, O’Connell D, Peterson J, Welch V, Losos M, Tugwell P. The Newcastle-Ottawa Scale (NOS) for assessing the quality of nonrandomised studies in meta-analyses. [URL: www.ohri.ca/programs/clinical epidemiology/ oxford.asp]

29. Kloss FR, Offermanns V, Kloss-Brandstätter A. CEComparison of allogeneic and autogenous bone grafts for augmentation of alveolar ridge defects-A 12-month retrospective radiographic evaluation. Clin Oral Implants Res. 2018 Oct 10. [Medline: $\underline{30303581]}$ [PMC free article: 6282851 ] [doi: $10.1111 /$ clr.13380]

30. Contar CM, Sarot JR, Bordini J Jr, Galvão GH, Nicolau GV, Machado MA. Maxillary ridge augmentation with fresh-frozen bone allografts. J Oral Maxillofac Surg. 2009 Jun;67(6):1280-5. [Medline: 19446217] [doi: 10.1016/j.joms.2008.11.010]

31. Nissan J, Mardinger O, Strauss M, Peleg M, Sacco R, Chaushu G. Implant-supported restoration of congenitally missing teeth using cancellous bone block-allografts. Oral Surg Oral Med Oral Pathol Oral Radiol Endod. 2011 Mar;111(3): 286-91. [Medline: 20674407] [doi: 10.1016/j.tripleo.2010.04.042]

32. Nissan J, Marilena V, Gross O, Mardinger O, Chaushu G. Histomorphometric analysis following augmentation of the posterior mandible using cancellous bone-block allograft. J Biomed Mater Res A. 2011 Jun 15;97(4):509-13. [Medline: 21509934] [doi: 10.1002/jbm.a.33096]

33. Orsini G, Stacchi C, Visintini E, Di Iorio D, Putignano A, Breschi L, Di Lenarda R. Clinical and histologic evaluation of fresh frozen human bone grafts for horizontal reconstruction of maxillary alveolar ridges. Int J Periodontics Restorative Dent. 2011 Sep-Oct;31(5):535-44. [Medline: 21845248]

34. Acocella A, Bertolai R, Ellis E 3rd, Nissan J, Sacco R. Maxillary alveolar ridge reconstruction with monocortical freshfrozen bone blocks: a clinical, histological and histomorphometric study. J Craniomaxillofac Surg. 2012 Sep;40(6): 525-33. [Medline: 22075326] [doi: 10.1016/j.jcms.2011.09.004]

35. Nissan J, Marilena V, Gross O, Mardinger O, Chaushu G. Histomorphometric analysis following augmentation of the anterior atrophic maxilla with cancellous bone block allograft. Int J Oral Maxillofac Implants. 2012 Jan-Feb;27(1):84-9. [Medline: 22299083]

36. Novell J, Novell-Costa F, Ivorra C, Fariñas O, Munilla A, Martinez C. Five-year results of implants inserted into freezedried block allografts. Implant Dent. 2012 Apr;21(2):129-35. [Medline: 22395472] [doi: 10.1097/ID.0b013e31824bf99f]

37. Chiapasco M, Colletti G, Coggiola A, Di Martino G, Anello T, Romeo E. Clinical outcome of the use of fresh frozen allogeneic bone grafts for the reconstruction of severely resorbed alveolar ridges: preliminary results of a prospective study. Int J Oral Maxillofac Implants. 2015 Mar-Apr;30(2):450-60. [Medline: 25830406] [doi: 10.11607/jomi.3763]

38. Aslan E, Gultekin A, Karabuda C, Mortellaro C, Olgac V, Mijiritsky E. Clinical, Histological, and Histomorphometric Evaluation of Demineralized Freeze-Dried Cortical Block Allografts for Alveolar Ridge Augmentation. J Craniofac Surg. 2016 Jul;27(5):1181-6. [Medline: 27380561] [doi: 10.1097/SCS.0000000000002548]

39. Deluiz D, Oliveira L, Fletcher P, Pires FR, Nunes MA, Tinoco EM. Fresh-Frozen Bone Allografts in Maxillary Alveolar Augmentation: Analysis of Complications, Adverse Outcomes, and Implant Survival. J Periodontol. 2016 Nov;87(11):1261-1267. [Medline: 27367419] [doi: 10.1902/jop.2016.160155]

40. Silva ER, Ferraz EP, Neto EC, Chaushu G, Chaushu L, Xavier SP. Volumetric Stability of Fresh Frozen Bone Blocks in Atrophic Posterior Mandible Augmentation. J Oral Implantol. 2017 Feb;43(1):25-32. [Medline: 27753539] [doi: 10.1563/aaid-joi-D-16-00095] 
41. Chaushu L, Chaushu G, Kolerman R, Vered M, Naishlos S, Nissan J. Anterior atrophic mandible restoration using cancellous bone block allograft. Clin Implant Dent Relat Res. 2019 Oct;21(5):903-909. [Medline: 30859715] [doi: $10.1111 /$ cid.12744]

42. Peleg M, Sawatari Y, Marx RN, Santoro J, Cohen J, Bejarano P, Malinin T. Use of corticocancellous allogeneic bone blocks for augmentation of alveolar bone defects. Int J Oral Maxillofac Implants. 2010 Jan-Feb;25(1):153-62. [Medline: 20209198]

43. Carinci F, Brunelli G, Franco M, Viscioni A, Rigo L, Guidi R, Strohmenger L. A retrospective study on 287 implants installed in resorbed maxillae grafted with fresh frozen allogenous bone. Clin Implant Dent Relat Res. 2010 Jun 1;12(2): 91-8. [Medline: 19076178] [doi: 10.1111/j.1708-8208.2008.00133.x]

44. Ahmadi RS, Sayar F, Rakhshan V, Iranpour B, Jahanbani J, Toumaj A, Akhoondi N. Clinical and Histomorphometric Assessment of Lateral Alveolar Ridge Augmentation Using a Corticocancellous Freeze-Dried Allograft Bone Block. J Oral Implantol. 2017 Jun;43(3):202-210. [Medline: 28326892] [doi: 10.1563/aaid-joi-D-16-00042]

45. Keith JD Jr, Petrungaro P, Leonetti JA, Elwell CW, Zeren KJ, Caputo C, Nikitakis NG, Schöpf C, Warner MM. Clinical and histologic evaluation of a mineralized block allograft: results from the developmental period (2001-2004). Int J Periodontics Restorative Dent. 2006 Aug;26(4):321-7. [Medline: 16939013]

46. Viscioni A, Rigo L, Franco M, Brunelli G, Avantaggiato A, Sollazzo V, Carinci F. Reconstruction of severely atrophic jaws using homografts and simultaneous implant placement: a retrospective study. J Oral Implantol. 2010;36(2):131-9. [Medline: 20426590] [doi: 10.1563/AAID-JOI-D-09-00025]

47. Chiapasco M, Di Martino G, Anello T, Zaniboni M, Romeo E. Fresh frozen versus autogenous iliac bone for the rehabilitation of the extremely atrophic maxilla with onlay grafts and endosseous implants: preliminary results of a prospective comparative study. Clin Implant Dent Relat Res. 2015 Jan;17 Suppl 1:e251-66. [Medline: 24373321] [doi: $10.1111 /$ cid.12191]

48. Nissan J, Gross O, Mardinger O, Ghelfan O, Sacco R, Chaushu G. Post-traumatic implant-supported restoration of the anterior maxillary teeth using cancellous bone block allografts. J Oral Maxillofac Surg. 2011 Dec;69(12):e513-8. [Medline: 21982693] [doi: 10.1016/j.joms.2011.08.002]

49. Barone A, Varanini P, Orlando B, Tonelli P, Covani U. Deep-frozen allogeneic onlay bone grafts for reconstruction of atrophic maxillary alveolar ridges: a preliminary study. J Oral Maxillofac Surg. 2009 Jun;67(6):1300-6. [Medline: 19446220] [doi: 10.1016/j.joms.2008.12.043]

50. Deluiz D, Oliveira LS, Pires FR, Tinoco EM. Time-dependent changes in fresh-frozen bone block grafts: tomographic, histologic, and histomorphometric findings. Clin Implant Dent Relat Res. 2015 Apr;17(2):296-306. [Medline: 23837530] [doi: $10.1111 / \mathrm{cid} .12108$ ]

51. Deluiz D, Oliveira LS, Pires FR, Tinoco EM. Time-dependent changes in fresh-frozen bone block grafts: tomographic, histologic, and histomorphometric findings. Clin Implant Dent Relat Res. 2015 Apr;17(2):296-306. [Medline: 29354249] [doi: 10.15171/joddd.2017.040]

52. Nissan J, Romanos GE, Mardinger O, Chaushu G. Immediate nonfunctional loading of single-tooth implants in the anterior maxilla following augmentation with freeze-dried cancellous block allograft: a case series. Int J Oral Maxillofac Implants. 2008 Jul-Aug;23(4):709-16. [Medline: 18807569]

53. Carinci F, Brunelli G, Zollino I, Franco M, Viscioni A, Rigo L, Guidi R, Strohmenger L. Mandibles grafted with fresh-frozen bone: an evaluation of implant outcome. Implant Dent. 2009 Feb;18(1):86-95. [Medline: 19212241] [doi: 10.1097/ID.0b013e318192cbbe]

54. Peleg M, Sawatari Y, Marx RN, Santoro J, Cohen J, Bejarano P, Malinin T. Use of corticocancellous allogeneic bone blocks for augmentation of alveolar bone defects. Int J Oral Maxillofac Implants. 2010 Jan-Feb;25(1):153-62. [Medline: 20209198]

55. Contar CM, Sarot JR, da Costa MB, Bordini J, de Lima AA, Alanis LR, Trevilatto PC, Machado MÂ. Fresh-frozen bone allografts in maxillary ridge augmentation: histologic analysis. J Oral Implantol. 2011 Apr;37(2):223-31. [Medline: 20545545] [doi: 10.1563/AAID-JOI-D-09-00108]

56. Deluiz D, Santos Oliveira L, Ramôa Pires F, Reiner T, Armada L, Nunes MA, Muniz Barretto Tinoco E. Incorporation and Remodeling of Bone Block Allografts in the Maxillary Reconstruction: A Randomized Clinical Trial. Clin Implant Dent Relat Res. 2017 Feb;19(1):180-194. [Medline: 27717113] [doi: 10.1111/cid.12441]

57. Sanz-Sánchez I, Carrillo de Albornoz A, Figuero E, Schwarz F, Jung R, Sanz M, Thoma D. Effects of lateral bone augmentation procedures on peri-implant health or disease: A systematic review and meta-analysis. Clin Oral Implants Res. 2018 Mar;29 Suppl 15:18-31. [Medline: 29498126] [doi: 10.1111/clr.13126]

58. Schwarz F, Giannobile WV, Jung RE; Groups of the 2nd Osteology Foundation Consensus Meeting. Evidence-based knowledge on the aesthetics and maintenance of peri-implant soft tissues: Osteology Foundation Consensus Report Part 2-Effects of hard tissue augmentation procedures on the maintenance of peri-implant tissues. Clin Oral Implants Res. 2018 Mar;29 Suppl 15:11-13. [Medline: 29498125] [doi: 10.1111/clr.13109]

59. Aloy-Prósper A, Peñarrocha-Oltra D, Peñarrocha-Diago M, Peñarrocha-Diago M. The outcome of intraoral onlay block bone grafts on alveolar ridge augmentations: a systematic review. Med Oral Patol Oral Cir Bucal. 2015 Mar 1;20(2): e251-8. [Medline: 25662543] [PMC free article: 4393991] [doi: 10.4317/medoral.20194] 
60. Albrektsson T, Zarb G, Worthington P, Eriksson AR. The long-term efficacy of currently used dental implants: a review and proposed criteria of success. Int J Oral Maxillofac Implants. 1986 Summer;1(1):11-25. [Medline: 3527955]

61. Laurell L, Lundgren D. Marginal bone level changes at dental implants after 5 years in function: a meta-analysis. Clin Implant Dent Relat Res. 2011 Mar;13(1):19-28. [Medline: 19681932] [doi: 10.1111/j.1708-8208.2009.00182.x]

62. Dellavia C, Giammattei M, Carmagnola D, Musto F, Canciani E, Chiapasco M. Iliac Crest Fresh-Frozen Allografts Versus Autografts in Oral Pre-Prosthetic Bone Reconstructive Surgery: Histologic and Histomorphometric Study. Implant Dent. 2016 Dec;25(6):731-738. [Medline: 27749380] [doi: 10.1097/ID.0000000000000451]

63. Garbin Junior EA, de Lima VN, Momesso GAC, Mello-Neto JM, Érnica NM, Magro Filho O. Potential of autogenous or fresh-frozen allogeneic bone block grafts for bone remodelling: a histological, histometrical, and immunohistochemical analysis in rabbits. Br J Oral Maxillofac Surg. 2017 Jul;55(6):589-593. [Medline: 28404212] [doi: 10.1016/j.bjoms.2017.03.004]

64. Elnayef B, Porta C, Suárez-López Del Amo F, Mordini L, Gargallo-Albiol J, Hernández-Alfaro F. The Fate of Lateral Ridge Augmentation: A Systematic Review and Meta-Analysis. Int J Oral Maxillofac Implants. 2018 May/Jun;33(3): 622-635. [Medline: 29763500] [doi: 10.11607/jomi.6290]

65. Jensen SS, Terheyden H. Bone augmentation procedures in localized defects in the alveolar ridge: clinical results with different bone grafts and bone-substitute materials. Int J Oral Maxillofac Implants. 2009;24 Suppl:218-36. [Medline: 19885447]

66. Peñarrocha-Diago M, Aloy-Prósper A, Peñarrocha-Oltra D, Calvo-Guirado JL, Peñarrocha-Diago M. Localized lateral alveolar ridge augmentation with block bone grafts: simultaneous versus delayed implant placement: a clinical and radiographic retrospective study. Int J Oral Maxillofac Implants. 2013 May-Jun;28(3):846-53. [Medline: 23748318] [doi: $10.11607 /$ jomi.2964]

67. Spin-Neto R, Stavropoulos A, Coletti FL, Faeda RS, Pereira LA, Marcantonio E Jr. Graft incorporation and implant osseointegration following the use of autologous and fresh-frozen allogeneic block bone grafts for lateral ridge augmentation. Clin Oral Implants Res. 2014 Feb;25(2):226-33. [Medline: 23346871] [doi: 10.1111/clr.12107]

\section{To cite this article:}

Starch-Jensen T, Deluiz D, Tinoco EMB.

Horizontal Alveolar Ridge Augmentation with Allogeneic Bone Block Graft Compared with Autogenous Bone Block Graft: a Systematic Review

J Oral Maxillofac Res 2020;11(1):e1

URL: http://www.ejomr.org/JOMR/archives/2020/1/e1/v11n1e1.pdf

doi: $10.5037 /$ jomr.2020.11101

Copyright (C) Starch-Jensen T, Deluiz D, Tinoco EMB. Published in the JOURNAL OF ORAL \& MAXILLOFACIAL RESEARCH (http://www.ejomr.org), 31 March 2020.

This is an open-access article, first published in the JOURNAL OF ORAL \& MAXILLOFACIAL RESEARCH, distributed under the terms of the Creative Commons Attribution-Noncommercial-No Derivative Works 3.0 Unported License, which permits unrestricted non-commercial use, distribution, and reproduction in any medium, provided the original work and is properly cited. The copyright, license information and link to the original publication on (http://www.ejomr.org) must be included. 
Appendix 1. Search history. Comparison of allogeneic bone block graft with autogenous bone block graft for horizontal ridge augmentation in implant reconstruction: a systematic review

\begin{tabular}{l|l|c|c}
\hline \multicolumn{1}{c|}{ Database } & \multicolumn{1}{c|}{ Interface } & Result & Date \\
\hline PubMed & PubMed.gov & 117 & 13.03 .2019 \\
\hline Embase & Embase.com & 54 & 13.03 .2019 \\
\hline Cochrane Library & Wiley & 72 & 13.03 .2019 \\
\cline { 1 - 2 } All & $\mathbf{2 4 3}$ & \\
\cline { 1 - 2 } After duplicate-removal with Endnote & $\mathbf{1 5 2}$ &
\end{tabular}

Appendix 2. PubMed search until the $13^{\text {th }}$ of March, 2019

\begin{tabular}{|c|c|c|}
\hline Search & Query & $\begin{array}{l}\text { Items } \\
\text { found }\end{array}$ \\
\hline \#42 & 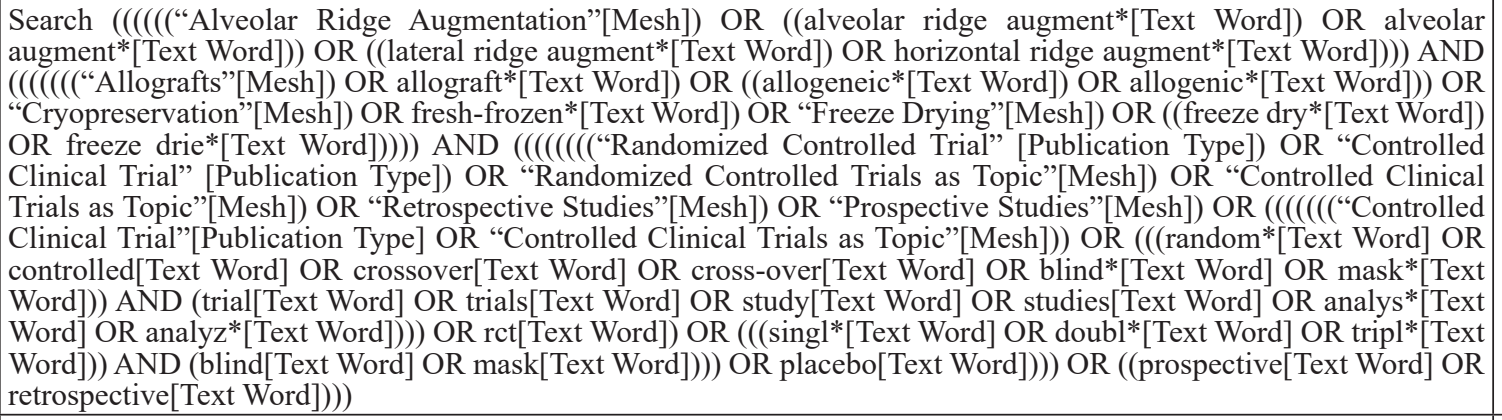 & 117 \\
\hline$\# 41$ & 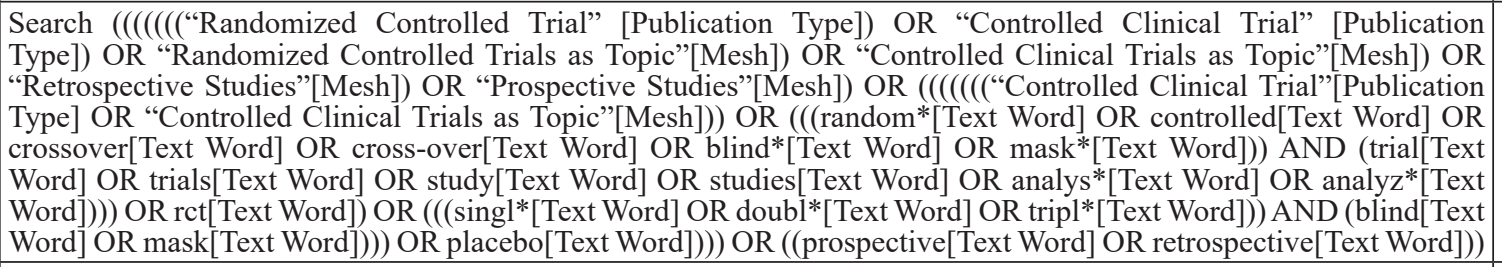 & 2955261 \\
\hline$\# 40$ & Search (prospective[Text Word] OR retrospective[Text Word]) & 1548133 \\
\hline \#39 & $\begin{array}{l}\text { Search }((((((\text { "Controlled Clinical Trial”[Publication Type] OR “Controlled Clinical Trials as Topic"[Mesh])) OR } \\
(((\text { random*[Text Word] OR controlled[Text Word] OR crossover[Text Word] OR cross-over[Text Word] OR } \\
\text { blind*[Text Word] OR mask*[Text Word] })) \text { AND (trial[Text Word] OR trials[Text Word] OR study[Text Word] OR } \\
\text { studies[Text Word] OR analys*[Text Word] OR analyz*[Text Word]))) OR rct[Text Word]) OR (((singl*[Text Word] } \\
\text { OR doubl*[Text Word] OR tripl*[Text Word])) AND (blind[Text Word] OR mask[Text Word]))) OR placebo[Text } \\
\text { Word]) }\end{array}$ & 1656743 \\
\hline$\# 38$ & Search "Prospective Studies"[Mesh] & 495282 \\
\hline$\# 35$ & Search "Retrospective Studies”[Mesh] & 734194 \\
\hline$\# 32$ & Search "Controlled Clinical Trials as Topic"[Mesh] & 128927 \\
\hline$\# 29$ & Search "Randomized Controlled Trials as Topic"[Mesh] & 123922 \\
\hline$\# 26$ & Search "Controlled Clinical Trial” [Publication Type] & 565794 \\
\hline$\# 24$ & Search "Randomized Controlled Trial” [Publication Type] & 477698 \\
\hline$\# 20$ & $\begin{array}{l}\text { Search ((((“Alveolar Ridge Augmentation”[Mesh]) OR ((alveolar ridge augment*[Text Word]) OR alveolar } \\
\text { augment*[Text Word])) OR ((lateral ridge augment*[Text Word]) OR horizontal ridge augment*[Text Word]))) AND } \\
(((((((“ A l l o g r a f t s ”[M e s h]) \text { OR allograft*[Text Word] }) \text { OR ((allogeneic*[Text Word]) OR allogenic*[Text Word])) OR } \\
\text { "Cryopreservation”[Mesh]) OR fresh-frozen*[Text Word]) OR "Freeze Drying”[Mesh]) OR ((freeze dry*[Text Word]) } \\
\text { OR freeze drie*[Text Word])) }\end{array}$ & 379 \\
\hline$\# 19$ & $\begin{array}{l}\text { Search (((((“"Allografts”[Mesh]) OR allograft*[Text Word] }) \text { OR ((allogeneic*[Text Word]) OR allogenic*[Text } \\
\text { Word])) OR "Cryopreservation”[Mesh]) OR fresh-frozen*[Text Word]) OR "Freeze Drying”[Mesh]) OR ((freeze } \\
\text { dry*[Text Word]) OR freeze drie*[Text Word] })\end{array}$ & 177542 \\
\hline$\# 18$ & Search (freeze dry*[Text Word]) OR freeze drie*[Text Word] & 20754 \\
\hline$\# 17$ & Search "Freeze Drying”[Mesh] & 12822 \\
\hline$\# 15$ & Search fresh-frozen*[Text Word] & 12493 \\
\hline$\# 14$ & Search "Cryopreservation”[Mesh] & 35168 \\
\hline$\# 11$ & Search (allogeneic*[Text Word]) OR allogenic*[Text Word] & 64534 \\
\hline$\# 10$ & Search allograft*[Text Word] & 67424 \\
\hline$\# 9$ & Search "Allografts”[Mesh] & 6588 \\
\hline \#6 & $\begin{array}{l}\text { Search ((“Alveolar Ridge Augmentation”[Mesh]) OR ((alveolar ridge augment*[Text Word]) OR alveolar } \\
\text { augment*[Text Word])) OR ((lateral ridge augment*[Text Word]) OR horizontal ridge augment*[Text Word]) }\end{array}$ & 4080 \\
\hline$\# 5$ & Search (lateral ridge augment*[Text Word]) OR horizontal ridge augment*[Text Word] & 118 \\
\hline$\# 4$ & Search (alveolar ridge augment*[Text Word]) OR alveolar augment*[Text Word] & 4061 \\
\hline$\# 3$ & Search “Alveolar Ridge Augmentation”[Mesh] & 3893 \\
\hline
\end{tabular}


Appendix 3. Embase search until the $13^{\text {th }}$ of March, 2019

\begin{tabular}{|c|c|c|}
\hline No. & Query & Results \\
\hline \#25 & \#16 AND \#24 & 54 \\
\hline \#24 & \#17 OR \#18 OR \#19 OR \#20 OR \#21 OR \#22 OR \#23 & 8348399 \\
\hline \#23 & 'retrospective':ti,ab, de OR 'prospective':ti,ab, de & 1889391 \\
\hline \#22 & 'prospective study'/exp & 501191 \\
\hline$\# 21$ & 'retrospective study'/de & 742766 \\
\hline$\# 20$ & $((($ single OR double OR triple) NEAR/2 (blind* OR mask*)):ti,ab,de) OR placebo:ti,ab, de & 553332 \\
\hline \#19 & $\begin{array}{l}(((\text { random* OR controlled* OR crossover OR ‘cross over’ OR blind* OR mask*) NEAR/3 (trial* OR study OR } \\
\text { studies OR analy*)):ti,ab,de) OR rct:ti,ab,de }\end{array}$ & 7025700 \\
\hline \#18 & 'randomized controlled trial'/exp & 537166 \\
\hline$\# 17$ & 'controlled clinical trial'/exp & 704690 \\
\hline$\# 16$ & \#6 AND \#15 & 142 \\
\hline$\# 15$ & \#7 OR \#8 OR \#9 OR \#10 OR \#11 OR \#12 OR \#13 OR \#14 & 314569 \\
\hline$\# 14$ & 'cryopreservation'/de & 38252 \\
\hline$\# 13$ & 'fresh frozen*' & 27926 \\
\hline$\# 12$ & 'freeze dry*' OR 'freeze drie*' & 28013 \\
\hline$\# 11$ & 'freeze drying'/de & 20066 \\
\hline$\# 10$ & 'allotransplantation'/de & 35557 \\
\hline \#9 & 'allogeneic*' OR 'allogenic*' & 111004 \\
\hline$\# 8$ & 'allograft*' & 104671 \\
\hline$\# 7$ & 'allograft'/exp & 39144 \\
\hline \#6 & \#1 OR \#2 OR \#3 OR \#4 OR \#5 & 1046 \\
\hline$\# 5$ & 'horizontal ridge augment*' & 53 \\
\hline$\# 4$ & 'lateral ridge augment*' & 55 \\
\hline$\# 3$ & 'alveolar ridge augment*' & 931 \\
\hline$\# 2$ & 'alveolar augment*' & 70 \\
\hline$\# 1$ & 'alveolar ridge augmentation'/de & 502 \\
\hline
\end{tabular}

Appendix 4. Cochrane Library search until the $13^{\text {th }}$ of March, 2019

\begin{tabular}{c|l|c}
\hline ID & \multicolumn{1}{|c|}{ Search } & Hits \\
\hline$\# 1$ & MeSH descriptor: [Alveolar Ridge Augmentation] explode all trees & 283 \\
\hline$\# 2$ & (alveolar ridge augment*):ti,ab,kw (Word variations have been searched) & 362 \\
\hline$\# 3$ & (alveolar augment*):ti,ab,kw & 513 \\
\hline$\# 4$ & (lateral ridge augment*):ti,ab,kw & 50 \\
\hline$\# 5$ & (horizontal ridge augment*):ti,ab,kw & 74 \\
\hline$\# 6$ & $\# 1$ or \#2 or \#3 or \#4 or \#5 & 527 \\
\hline$\# 7$ & MeSH descriptor: [Allografts] explode all trees & 139 \\
\hline$\# 8$ & (allograft*):ti,ab,kw & 3439 \\
\hline$\# 9$ & (allogeneic* or allgenic*):ti,ab,kw & 3727 \\
\hline$\# 10$ & MeSH descriptor: [Cryopreservation] explode all trees & 535 \\
\hline$\# 11$ & (fresh frozen*):ti,ab,kw & 1102 \\
\hline$\# 12$ & MeSH descriptor: [Freeze Drying] explode all trees & 184 \\
\hline$\# 13$ & (freeze dry*):ti,ab,kw & 288 \\
\hline$\# 14$ & (freeze drie*):ti,ab,kw & 514 \\
\hline$\# 15$ & $\# 7$ or \#8 or \#9 or \#10 or \#11 or \#12 or \#13 or \#14 & 8749 \\
\hline$\# 16$ & $\# 6$ and \#15 in Trials & 72 \\
\hline & &
\end{tabular}

